\title{
IMAGE CORRELATION BETWEEN FACET EFFUSION AND LUMBAR INSTABILITY
}

\author{
CORRELAÇÃO POR IMAGEM ENTRE LÍQUIDO FACETÁRIO E INSTABILIDADE LOMBAR
} CORRELACIÓN POR IMAGEN ENTRE DERRAME FACETARIO Y INESTABILIDAD LUMBAR

\author{
Mauro Antonio Fernandes Junior, ${ }^{1}$ Emiliano Neves Vialle, ${ }^{1}$ Rafael Luiz Pinto, ${ }^{2}$ Felipe de Negreiros Nanni, ${ }^{1}$ Luiz Roberto Vialle ${ }^{3}$ \\ 1. Pontifícia Universidade Católica do Paraná - PUCPR, Hospital Universitário Cajuru - HUC, Spine Surgery Group, Curitiba, PR, Brazil. \\ 2. Pontifícia Universidade Católica do Paraná - PUCPR, Escola de Medicina, Curitiba, PR, Brazil. \\ 3. Pontifícia Universidade Católica do Paraná - PUCPR, Escola de Medicina, Department of Orthopedics and Traumatology, Curitiba, PR, Brazil.
}

\begin{abstract}
Objective: To assess the incidence of facet effusion in lumbosacral spine magnetic resonance imaging (MRI) and the relationship with radiographic segmental instability in patients submitted to spinal surgery. Methods: Retrospective cohort study of patients submitted to lumbosacral spine surgery over a period of three years, through the evaluation of dynamic radiographs (X-ray) motion and facet effusion in axial section of MRI. Instability was defined as vertebral translation $>3 \mathrm{~mm}$ or intervertebral angle $>10^{\circ}$, and facet effusion as fluid in the facet joints $>1.5 \mathrm{~mm}$. Results: The total number of patients that fulfilled the criteria for analysis was 244 , of which 47 presented movement $(\leq 3 \mathrm{~mm})$ and 31 presented excessive movement $(>3 \mathrm{~mm}), 115$ had facet effusion $(\leq 1.5 \mathrm{~mm})$ and 46 presented excessive fluid $(>1.5 \mathrm{~mm})$. Statistical analysis did not demonstrate a significant association between increased segmental movement and facet effusion $(p=0.150)$. Conclusions: The total incidence of facet effusion was $47.1 \%$ and the excessive fluid was $18.9 \%$. There was no association between facet effusion in MRI and instability in dynamic X-ray. MRI does not replace dynamic X-ray in flexion and extension in the evaluations of lumbar instability. Level of evidence III; Retrospective Cohort.
\end{abstract}

Keywords: Spine; Joint Instability; Spondylolisthesis.

\section{RESUMO}

Objetivo: Avaliar a incidência de líquido facetário na ressonância magnética (RNM) de coluna lombossacra e a relação com instabilidade segmentar radiográfica em pacientes submetidos à cirurgia da coluna vertebral. Métodos: Coorte retrospectivo de pacientes submetidos à cirurgia da coluna lombossacra, em um período de três anos, através da avaliação do movimento na radiografia (RX) dinâmica e presença de líquido facetário no corte axial da RNM. Considerou-se movimento excessivo a translação vertebral $>3 \mathrm{~mm}$ ou angulação intervertebral $>10^{\circ}$. Quanto ao líquido excessivo, a presença de líquido facetário $>1,5 \mathrm{~mm}$. Resultados: 244 pacientes preencheram critérios para análise. 47 apresentaram movimento ( $\leq 3 \mathrm{~mm}$ ) e 31 apresentaram movimento excessivo (>3 mm). 115 apresentaram líquido facetário ( $\leq 1,5 \mathrm{~mm})$ e 46 apresentaram líquido excessivo (>1,5 mm). A análise estatística não demonstrou associação significativa entre o movimento segmentar aumentado e a presença de líquido facetário ( $p=0,150)$. Conclusão: A incidência total de líquido facetário foi de 47,1\% e de líquido excessivo 18,9\%. Não houve associação entre líquido facetário na RNM e instabilidade no RX dinâmico. A RNM não substitui o RX em flexão e extensão na avaliação de instabilidade lombar. Nível de evidência III; Coorte Retrospectiva.

Descritores: Coluna Vertebral; Instabilidade Articular; Espondilolistese.

\section{RESUMEN}

Objetivo: Evaluar la incidencia de derrame facetario en la resonancia magnética (RM) de la columna lumbosacra y la relación con la inestabilidad segmentaria radiográfica en pacientes sometidos a cirugía de columna vertebral. Métodos: Estudio retrospectivo de cohorte de pacientes sometidos a cirugía de columna lumbosacra en un período de tres años, mediante la evaluación del movimiento en las radiografías (RX) dinámicas y derrame facetario en el corte axial de la RM. La inestabilidad se definió como traslación vertebral $>3 \mathrm{~mm}$ o ángulo intervertebral > 10 y derrame facetario como líquido en las articulaciones facetarias $>1,5 \mathrm{~mm}$. Resultados: El número total de pacientes que cumplieron con los criterios para análisis fue 244 , de los cuales 47 presentaron movimientos ( $\leq 3 \mathrm{~mm}$ ) y 31 presentaron movimientos excesivos (> $3 \mathrm{~mm})$, 115 tuvieron derrame facetario $(\leq 1,5 \mathrm{~mm})$ y 46 presentaron exceso de líquido $(>1,5 \mathrm{~mm})$. El análisis estadístico no demostró asociación significativa entre el aumento del movimiento segmentario y el derrame facetario $(p=0,150)$. Conclusiones: La incidencia total de derrame facetario fue del $47,1 \%$ y el líquido excesivo 18,9\%. No hubo asociación entre el derrame facetario en la RM y la inestabilidad en los rayos X dinámicos. La RM no reemplaza la radiografía dinámica en flexión y extensión en las evaluaciones de la inestabilidad lumbar. Nivel de evidencia III; Cohorte Retrospectivo.

Descriptores: Columna Vertebral; Inestabilidad de la Articulación; Espondilolistesis.

\section{INTRODUCTION}

Segmental instability is an important factor that affects the prognosis of spinal surgery and is used by many surgeons as a criterion for fixation and arthrodesis. ${ }^{1-5}$ Targeting patients properly for this type of surgery requires precise identification of the unstable segments. ${ }^{1,4,6}$ The biomechanical concept of segmental stability is widely known, but the radiological definition of instability is under discussion. 2,7,8 Several methods have been developed over the last few decades to assess the presence of instability radiographically. ${ }^{8}$ In this context, magnetic resonance imaging (MRI) of the lumbar 
spine, currently more available, has become a routine study in the evaluation of patients with low back pain. ${ }^{5,9,10}$ This modality provides, among other information, important data about disc degeneration and compression of the neural elements. ${ }^{5}$ However, an MRI with the patient in the supine position presents limitations in the evaluation of subtle deformities that appear only when the patient is standing, for example, some cases of vertebral translation.,9-13

The presence of hyperintense signals in T2 in the facet joints in MRI axial cuts of the lumbar spine has been being discussed for many years. ${ }^{5} \mathrm{~T} 2$ weightings are used, since, differently from the T1 used in the evaluation of the normal anatomy, T2 weightings show extracellular water as a high-intensity signal. ${ }^{14}$ The initial studies observed that these signal alterations were produced by synovial liquid, a result of joint degeneration. ${ }^{5,9,14}$ However, only recently has facet effusion been associated with instability. ${ }^{5}$

The objective of this study is to evaluate the incidence of facet effusion in MRls of the lumbosacral spine and its relationship with radiographic segmental instability in patients who have undergone spinal surgery.

\section{METHODS}

This is a retrospective cohort study of patients who underwent lumbosacral spine surgery at our institution between January 1 , 2014 and December 31, 2016. After obtaining approval from the Institutional Review Board (opinion no. 089852/2013), we considered patients for the study who were older than 18 years of age, had undergone surgery in segments L4-L5 and L5-S1, and who had both a dynamic radiograph (X-ray) and MRI of the lumbosacral spine. The exclusion criteria were prior fix action or arthrodesis in the lumbosacral spine, scoliosis defined as $>5^{\circ}$ at a single level or $>10^{\circ}$ for the whole curve, dysplasia, infection, neoplasia, fracture, synovial cyst, and X-ray and MRI with more than a year apart. All patients included signed the informed consent form.

For the dynamic X-ray, the patient initially sat on a bench with the soles of the feet flat on the floor and the upper limbs crossed at chest level. ${ }^{1,15}$ The patient was then instructed to bend forward as much as possible for the X-ray in flexion. ${ }^{1,15}$ For the X-ray in extension, performed standing, the patient was asked to perform maximum extension. ${ }^{1,15}$ In previous studies, this dynamic X-ray technique demonstrated optimization of segmental movement of the spine, presenting a high rate of intra- and interobserver concordance. ${ }^{1,15}$

Movement was evaluated in the lateral incidence of the X-ray. ${ }^{11,16}$ Movement was defined as the anterior translation of the cranial vertebral body over the caudal vertebral body in the sagittal plane. ${ }^{16}$ The radiographic measurements were taken using three points of reference: the anterior and posterior extremities of the upper plate of the caudal vertebra and the posterior extremity of the lower plate of the cranial vertebra. ${ }^{3,17} \mathrm{~A}$ line was drawn connecting the anterior and posterior extremities of the upper vertebral plate of the caudal vertebra. ${ }^{3,17}$ The distance between the two perpendicular lines passing through the posterior extremity of the vertebral body of the upper vertebra and the posterior extremity of the lower vertebra was obtained in flexion and extension. 3,17 The amount of sagittal translation was established as the displacement difference in millimeters. ${ }^{3,17}$ The angulation of the segment was also measured as the difference in degrees between the angles in flexion and extension. ${ }^{3,17}$ Movement was classified into three groups: without movement, with movement $\left(\leq 3 \mathrm{~mm}\right.$ and $\left.\leq 10^{\circ}\right)$, and with excessive movement $\left(>3 \mathrm{~mm}\right.$ and $\left.>10^{\circ}\right) \cdot{ }^{3,16,18}$ (Figure 1)

Facet effusion was studied in axial T2-weighted cuts in the lumbosacral MRI to analyze its presence and quantity. 9,11 According to Chaput et al., facet effusion is defined as a curvilinear, measurable, hyperintense signal in the facet joint that resembles cerebrospinal fluid in the axial cut in T2.9,10,11 The thickness of the facet effusion was assessed by taking into account the perpendicular measurement between the medial and lateral borders of the facet joint that appears to have the greatest amount of liquid. ${ }^{9,10,11}$ Facet effusion was classified into three groups: without effusion, with effusion $(\leq 1.5 \mathrm{~mm})$, and with excessive effusion $(>1.5 \mathrm{~mm}) .{ }^{4}$ (Figure 2$)$

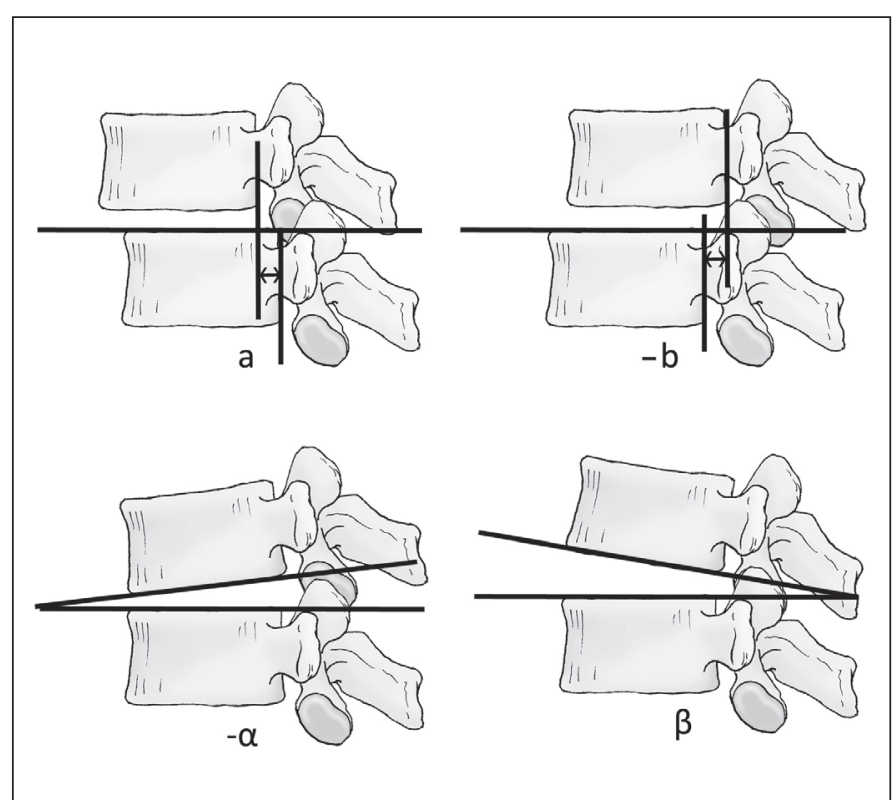

Figure 1. Evaluation of the dynamic radiograph. Sagittal translation is the distance between the perpendicular lines that pass through the posterior edges of the vertebral bodies in flexion and extension. Translation $=a-(-b)$. Angulation is the difference between the intervertebral angles in flexion and extension. Angulation $=\beta-(-\alpha)^{3}$

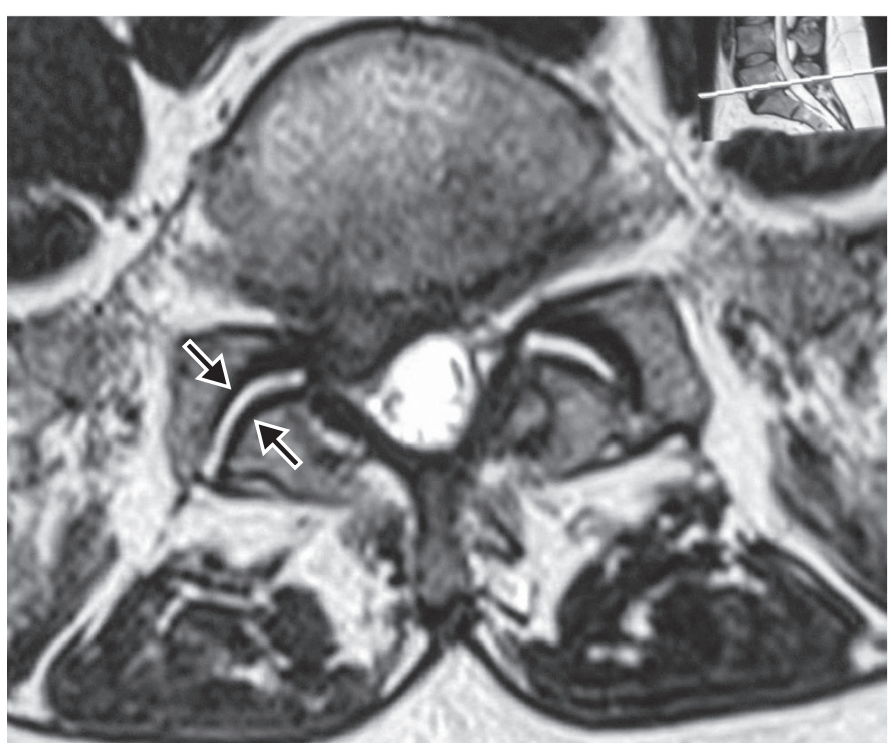

Figure 2. Axial cut of T2-weighted MRI showing facet effusion in segment $\mathrm{L} 5-\mathrm{S} 1^{9}$.

The patients were also evaluated for the presence of spondylolisthesis in the lateral X-ray of the lumbosacral spine in the standing position. The objective of the analysis was to choose between decompression and decompression and arthrodesis for surgical treatment.

All the measurements from radiographic and magnetic resonance studies were taken by an independent examiner, not involved in patient care. We tested the null hypothesis of independence between movement and effusion versus the alternative hypothesis of dependence. The results were described as frequencies and percentages. To evaluate the association between the two categorical variables, we used Fisher's exact test or the Chi-square test. P-values less than 0.05 indicated statistical significance. The data were analyzed with the IBM SPSS Statistics v.20.0 computational program (IBM Corp., Armonk, NY). 


\section{RESULTS}

Two hundred and forty-four patients met the criteria and were evaluated between 2014 and 2016. Most of these individuals were 70 years of age or younger, with 109 patients in the $\leq 50$ years of age group, 105 patients in the 51-70 years of age group, and 30 patients $>70$ years of age. Among the 111 male patients, $33.3 \%$ had listhesis. Among the women, this percentage was $51.1 \%$. (Table 1)

According to the dynamic X-rays, 166 patients presented no movement, 47 presented movement $(\leq 3 \mathrm{~mm})$, and 31 presented excessive movement ( $>3 \mathrm{~mm}$ ). In the MRI evaluation, 83 did not present facet effusion, 115 presented effusion $(\leq 1.5 \mathrm{~mm})$ and 46 presented excessive effusion $(>1.5 \mathrm{~mm}$ ). In the population studied, the incidence of facet effusion was $47.1 \%$, while that of excessive effusion was $18.9 \%$. In turn, the incidence of effusion in the patients with movement was $53.2 \%$ and excessive effusion in patients with movement was $29 \%$. One hundred and sixty-five patients $(67.6 \%)$ underwent arthrodesis.

Statistical analysis results indicated no significant association between segmental movement and the presence of effusion. (Table 2) It was also not possible to determine any significant association between effusion and an indication of arthrodesis. (Table 3) Confirming data from the literature, a significant association was found between sex and the presence of listhesis. (Table 4)

Table 1. Characteristics of patients submitted to lumbosacral spine surgery.

\begin{tabular}{c|c|c|c}
\hline Variable & Classification & $\mathbf{n}$ & $\%$ \\
\hline Age (years) & $\leq 50$ & 109 & 44.7 \\
\hline & $51-70$ & 105 & 43.0 \\
\hline Sex & $>70$ & 30 & 12.3 \\
\hline & Male & 111 & 45.5 \\
\hline Listhesis & Female & 133 & 54.5 \\
\hline & With listhesis & 105 & 43.0 \\
\hline Movement & Without listhesis & 139 & 57.0 \\
\hline & With movement & 47 & 19.3 \\
\hline & Without movement & 166 & 68.0 \\
\hline Facet effusion & Excessive movement & 31 & 12.7 \\
\hline & With effusion & 115 & 47.1 \\
\hline & Without effusion & 83 & 34.0 \\
\hline Arthrodesis & Excessive effusion & 46 & 18.9 \\
\hline & Yes & 165 & 67.6 \\
\hline & No & 79 & 32.4 \\
\hline
\end{tabular}

Table 2. Association between movement (X-ray) and facet effusion (MRI).

\begin{tabular}{c|c|c|c}
\hline \multirow{2}{*}{ Facet Effusion } & \multicolumn{3}{|c}{ Movement (X-ray) } \\
\cline { 2 - 4 } & $\begin{array}{c}\text { Without } \\
\text { movement }\end{array}$ & $\begin{array}{c}\text { With } \\
\text { movement }\end{array}$ & $\begin{array}{c}\text { Excessive } \\
\text { movement }\end{array}$ \\
\hline Without effusion & 64 & 11 & 8 \\
\hline & $38.6 \%$ & $23.4 \%$ & $25.8 \%$ \\
\hline With effusion & 76 & 25 & 14 \\
\hline & $45.8 \%$ & $53.2 \%$ & $45.2 \%$ \\
\hline Excessive effusion & 26 & 11 & 9 \\
\hline & $15.7 \%$ & $23.4 \%$ & $29.0 \%$ \\
\hline Total & 166 & 47 & 31 \\
\hline
\end{tabular}

P-value: 0.150 (Chi-square test, $p<0.05$ ).

Table 3. Association between facet effusion (MRI) and indication of arthrodesis.

\begin{tabular}{c|c|c|c}
\hline \multirow{2}{*}{ Arthrodesis } & \multicolumn{3}{|c}{ Facet Effusion } \\
\cline { 2 - 4 } & $\begin{array}{c}\text { Without } \\
\text { effusion }\end{array}$ & $\begin{array}{c}\text { With } \\
\text { effusion }\end{array}$ & $\begin{array}{c}\text { Excessive } \\
\text { effusion }\end{array}$ \\
\hline No & 31 & 34 & 14 \\
\hline Yes & $37.3 \%$ & $29.6 \%$ & $30.4 \%$ \\
\hline Total & 52 & 81 & 32 \\
\hline & $62.7 \%$ & $70.4 \%$ & $69.6 \%$ \\
\hline
\end{tabular}

P-value: 0.489 (Chi-square test, $p<0.05)$.
Table 4. Association between sex and spondylolisthesis.

\begin{tabular}{c|c|c}
\hline \multirow{2}{*}{ Spondylolisthesis } & \multicolumn{2}{|c}{ Sex } \\
\cline { 2 - 3 } & Male & Female \\
\hline \multirow{2}{*}{ No } & 74 & 65 \\
\cline { 2 - 3 } & $66.7 \%$ & $48.9 \%$ \\
\hline \multirow{2}{*}{ Yes } & 37 & 68 \\
\cline { 2 - 3 } & $33.3 \%$ & $51.1 \%$ \\
\hline Total & 111 & 133 \\
\hline
\end{tabular}

P-value: 0.006 (Fisher's exact test, $p<0.05$ )

\section{DISCUSSION}

Low back pain is a common complaint, affecting approximately $84 \%$ of the population at some point in their lives. ${ }^{8}$ In spite of the technological advances in diagnostic methods, the identification of the specific cause of low back pain can be costly. ${ }^{1}$ It is believed that segmental instability is one of the main causes of pain. ${ }^{1,3}$

Dupuis et al. described instability in degenerative spondylolisthesis as abnormal movement exhibited by a mobile lumbar segment. ${ }^{6,19}$ Radiography of the lumbar spine in the standing position is currently accepted as a study of the lumbar spine in functional position, providing relevant instability data. ${ }^{5}$ In patients with spondylolisthesis, Lowe et al. observed and increase of $2 \mathrm{~mm}$ or more in vertebral translation in the standing versus the supine position. 5,20 Boxall et al. observed similar variations in the slip angle. ${ }^{5,21}$

Although several studies question its reproducibility and validation, traditionally, the most accepted method for evaluating anteroposterior lumbar instability is the dynamic X-ray (flexion and maximum extension). ${ }^{1,3,4,8-11,14,22}$ The amount of translation and rotation in the sagittal plane is calculated and compared with normality variations. ${ }^{1}$

White and Panjabi defined radiographic instability as translation in the sagittal plane greater than $4.5 \mathrm{~mm}$ or greater than $15 \%$ of the vertebral body, as well as rotation in the sagittal plane greater than $15^{\circ}$ in segments L1-L2, L2-L3, and L3-L4, greater than $20^{\circ}$ in segment L4-L5, and greater than $25^{\circ}$ in segment L5-S1.1,17 Other authors established $4 \mathrm{~mm}$ of translation or $10^{\circ}$ of angulation as reference values. ${ }^{3,23,24}$ In their evaluation of translation in dynamic X-rays of asymptomatic patients, Boden et al. defined a value of $3 \mathrm{~mm}$ as the standard. ${ }^{6,18}$

Many studies have described the association between facet effusion and lumbar segmental instability. Ben-Galim and Reitman discussed the "distended facet sign", which they believed to be indicative of position-dependent canal stenosis and degenerative spondylolisthesis. ${ }^{5,25} \mathrm{Kim}$ and Wang treated the facet effusion sign as an intermediate phase in the progression of degeneration. ${ }^{5,26}$ Other studies also have pointed to an association between facet joint degeneration and disc degeneration, which are important contributing factors to lumbar spine instability. ${ }^{14,27}$ Rihn et al. indicated that the presence of facet effusion has a predictive value of $82 \%$ for instability in the dynamic X-ray. ${ }^{14,16}$ Chaput et al. concluded that more than $1.5 \mathrm{~mm}$ of facet effusion was associated with movement. ${ }^{10,16}$

These and other studies on the topic used the two-dimensional plane as a reference. ${ }^{4}$ Although we also used the two-dimensional plane and a low instability threshold $\left(>3 \mathrm{~mm}\right.$ and $>10^{\circ}$ ) for our standard, it was not possible to confirm an association between facet effusion and radiographic instability in the sagittal plane in our study. It is possible that there are situations in which facet effusion is associated with a condition of three-dimensional instability not detected with the dynamic radiograph. ${ }^{4}$

Facet effusion can be caused by other factors in addition to segmental instabilty. ${ }^{4}$ It can be the result of osteoarthritis of the facet joint or of other synovial joints, such as the knee and the hip, as well as of pseudo-gout. ${ }^{28-30}$

Recently, Tamai et al. demonstrated that in patients without radiographic instability, facet joint effusion has no effect of the outcome of minimally invasive decompression surgery. ${ }^{4}$ The results of our study suggest that decompression surgery can be performed in patients with facet effusion but without instability in the dynamic $X$ -ray. ${ }^{4}$ In the same vein, in our study we observed that the presence 
of facet effusion does not influence a therapeutic decision between decompression and decompression and arthrodesis.

Several limitations of our study should be considered. The patients were evaluated retrospectively, which may have introduced an analysis bias. Despite the large number of patients evaluated (244 patients), the samples with excessive movement and excessive effusion were small a 32 and 46 patients, respectively.

\section{CONCLUSION}

The incidence of facet effusion in patients submitted to lumbar spine surgery was $47.1 \%$, while the incidence of excessive liquid was $18.8 \%$. The incidence of movement was $19.3 \%$ and of excessive movement was $12.7 \%$. There was no association between facet effusion in the magnetic resonance and excessive movement in the dynamic radiograph. The presence of effusion did not influence the choice of treatment between decompression or decompression and arthrodesis. Therefore, MRI does not replace X-ray in flexion and extension in the evaluation of lumbar instability.

All authors declare no potential conflict of interest related to this article.

CONTRIBUTION OF THE AUTHORS: Each author made significant individual contributions to this manuscript. Concept and study design: MAFJ (0000-0003-3979-607X)*, ENV (0000-0003-1157-4889)*, and LRV (0000-0002-0638-4311)*. IRB approval: ENV (0000-0003-1157-4889)*. Data acquisition: MAFJ (0000-0003-3979-607X)*. Data analysis and interpretation: MAFJ (0000-0003-3979-607X)*, ENV (0000-0003-1157-4889)*, and RLP (0000-00022096-6465)*. Article development: MAFJ (0000-0003-3979-607X)* and ENV (0000-0003-1157-4889)*. Tables and figures: FNN (0000-0001-6959-8862) ${ }^{\star}$ Critical review of the article: ENV (0000-0003-1157-4889)* and LRV (0000-0002-0638-4311)*. Review of the final article for submission: MAFJ (0000-00033979-607X)*, ENV (0000-0003-1157-4889)*, and LRV (0000-0002-0638-4311)*. *ORCID (Open Researcher and Contributor ID).

\section{REFERENCES}

1. Fritz JM, Piva SR, Childs JD. Accuracy of the clinical examination to predict radiographic instability of the lumbar spine. Eur Spine J. 2005;14(8):743-50.

2. Hasegawa K, Kitahara K, Shimoda H, Ishii K, Ono M, Homma T, et al. Lumbar degenerative spondylolisthesis is not always unstable: clinicobiomechanical evidence. Spine (Phila Pa 1976). 2014;39(26):2127-35

3. Iguchi T, Kanemura A, Kasahara K, Kurihara A, Doita M, Yoshiya S. Age distribution of three radiologic factors for lumbar instability: probable aging process of the instability with disc degeneration. Spine (Phila Pa 1976). 2003;28(23):2628-33.

4. Tamai K, Kato M, Konishi S, Matsumura A, Hayashi K, Nakamura H. Facet Effusion without Radiographic Instability Has No Effect on the Outcome of Minimally Invasive Decompression Surgery. Global Spine J. 2017;7(1):21-7.

5. Schinnerer KA, Katz LD, Grauer JN. MR findings of exaggerated fluid in facet joints predicts instability. Clin Spine Surg. 2008:21(7):468-72

6. Simmonds AM, Rampersaud YR, Dvorak MF, Dea N, Melnyk AD, Fisher CG. Defining the inherent stability of degenerative spondylolisthesis: a systematic review. J Neurosurg Spine. 2015;23(2):178-89.

7. Hasegawa K, Kitahara K, Shimoda H, Hara T. Facet joint opening in lumbar degenerative diseases indicating segmental instability. J Neurosurg Spine. 2010;12(6):687-93.

8. Pieper CC, Groetz SF, Nadal J, Schild HH, Niggemann PD. Radiographic evaluation of ventral instability in lumbar spondylolisthesis: do we need extension radiographs in routine exams? Eur Spine J. 2014;23(1):96-101.

9. Caterini R, Mancini F, Bisicchia S, Maglione P, Farsetti P. The correlation between exaggerated fluid in lumbar facet joints and degenerative spondylolisthesis: prospective study of 52 patients. J Orthop Traumatol. 2011:12(2):87-91.

10. Chaput C, Padon D, Rush J, Lenehan E, Rahm M. The significance of increased fluid signa on magnetic resonance imaging in lumbar facets in relationship to degenerative spondylolisthesis. Spine (Phila Pa 1976). 2007:32(17):1883-7.

11. Cho BY, Murovic JA, Park J. Imaging correlation of the degree of degenerative L4-5 spondylolisthesis with the corresponding amount of facet fluid. J Neurosurg Spine. 2009;11(5):614-9

12. Kuhns BD, Kouk S, Buchanan C, Lubelski D, Alvin MD, Benzel EC, et al. Sensitivity of magnetic resonance imaging in the diagnosis of mobile and nonmobile L4-L5 degenerative spondylolisthesis. Spine J. 2015;15(9):1956-62.

13. Lattig F, Fekete TF, Grob D, Kleinstück FS, Jeszenszky D, Mannion AF. Lumbar facet joint effusion in MRI: a sign of instability in degenerative spondylolisthesis? Eur Spine J. 2012;21(2):276-81

14. Rihn JA, Lee JY, Khan M, Ulibarri JA, Tannoury C, Donaldson III WF, et al. Does lumbar facet fluid detected on magnetic resonance imaging correlate with radiographic instability in patients with degenerative lumbar disease? Spine (Phila Pa 1976). 2007:32(14):1555-60.

15. Putto $E$, Tallroth $K$. Extension-flexion radiographs for motion studies of the lumbar spine. A comparison of two methods. Spine (Phila Pa 1976). 1990;15(2):107-10.

16. Even JL, Chen AF, Lee JY. Imaging characteristics of "dynamic" versus "static" spondylolisthesis: analysis using magnetic resonance imaging and flexion/extension films. Spine J. 2014;14(9):1965-9.

17. White AA, Panjabi MM. Clinical biomechanics of the spine, 2 nd ed. Philadelphia: Lippincott; 1990. p. 23-45

18. Boden SD, Wiesel SW. Lumbosacral segmental motion in normal individuals. Have we been measuring instability properly? Spine (Phila Pa 1976). 1990;15(6):571-6.

19. Dupuis PR, Yong-Hing K, Cassidy JD, Kirkaldy-Willis WH. Radiologic diagnosis of degenerative lumbar spinal instability. Spine (Phila Pa 1976). 1985;10(3):262-76.

20. Lowe RW, Hayes TD, Kaye J, Bagg RJ, Luekens CA. Standing roentgenograms in spondylolisthesis. Clin Orthop Relat Res. 1976:(117):80-4.

21. Boxall D, Bradford DS, Winter RB, Moe JH. Management of severe spondylolisthesis in children and adolescents. J Bone Joint Surg Am. 1979;61(4):479-95.

22. Knutsson $\mathrm{F}$. The instability associated with disk degeneration in the lumbar spine. Acta Radiologica. 1944;25(5-6):593-609.

23. Herkowitz HN. Spine update. Degenerative lumbar spondylolisthesis. Spine (Phila Pa 1976). 1995:20(9):1084-90

24. Muggleton JM, Kondracki M, Allen R. Spinal fusion for lumbar instability: does it have a scientific basis? J Spinal Disord. 2000;13(3):200-4.

25. Ben-Galim P, Reitman CA. The distended facet sign: an indicator of position-dependent spinal stenosis and degenerative spondylolisthesis. Spine J. 2007;7(2):245-8.

26. Kim KA, Wang MY. MRI-based morphological predictors of SPECT positive facet arthropathy in patients with axial back pain. Neurosurgery. 2006;59(1):147-56.

27. Fujiwara A, Lim TH, An HS, Tanaka N, Jeon CH, Andersson GB, et al. The effect of disc degeneration and facet joint osteoarthritis on the segmental flexibility of the lumbar spine. Spine (Phila Pa 1976). 2000;25(23):3036-44.

28. Pathria M, Sartoris DJ, Resnick D. Osteoarthritis of the facet joints: accuracy of oblique radiographic assessment. Radiology. 1987;164(1): 227-30.

29. Gellhorn AC, Katz JN, Suri P. Osteoarthritis of the spine: the facet joints. Nat Rev Rheumatol. 2013:9(4):216-24

30. Fujishiro T, Nabeshima Y, Yasui S, Fujita I, Yoshiya S, Fujii H. Pseudogout attack of the lumbar facet joint: a case report. Spine (Phila Pa 1976). 2002;27(17):E396-8. 